\title{
粒状路盤材の力学特性評価に対する 不飽和三軸試験機の適用
}

\author{
石川達也 $^{1} \cdot$ 張媛 $^{2} \cdot$ 所哲也 ${ }^{3}$ \\ 1 フェロー会員 博 (工) 北海道大学准教授 大学院工学研究院（ $\bar{T} 060-8628$ 北海道札幌市北区北 13 条西 8) \\ E-mail : t-ishika@eng.hokudai.ac.jp \\ 2 北海道大学 大学院工学院（ $\bar{T} 060-8628$ 北海道札幌市北区北 13 条西 8) \\ ${ }^{3}$ 正会員 博 (工) 苫小牧工業高等専門学校助教 環境都市工学科（ $\bar{T} 059-1275$ 北海道苫小牧市字錦岡 443)
}

\begin{abstract}
本研究では，微細多孔質膜を利用した中型不飽和三軸試験機を製作し，豊浦砂と下層路盤に使用されるク ラッシャラン（C-40）の保水性試験・三軸圧縮試験を行い，その基本的な性能の確認と試験方法の有用性・ 実用性を検討するとともに，含水状態の異なる C-40 の力学挙動を評価した。その結果，不飽和下層路盤材 の要素試験に対する本研究で開発した試験機および提案する試験方法の適用性・有用性を試験時間の短縮と 試験結果の妥当性の観点から示した。また，積雪寒冷地の融解期に観測される下層路盤の含水比上昇が，下 層路盤材の強度や剛性を低下させ，下層路盤の支持力性能を変化させることを明らかにした。
\end{abstract}

Key Words : base course matrial, unsaturated soil, triaxial test, pressure membrane method

\section{1.はじめに}

北海道のような積雪寒冷地では，冬期に凍結・凍上し た下層路盤や路床が，融解期には融雪水の流入やアイス レンズの融解により含水比が上昇し路床や路盤の強度が 一時的に低下寸る ${ }^{1)}$.この結果, アスファルト混合物層に 亀甲状ひび割れが生じるなどして走行路機能の劣化・喪 失 (走行路面変状) を早めるとされており ${ }^{2)}$, 寒冷地域特 有の地盤の凍結融解現象が舗装構造の疲労破壊寿命の減 少に強い影響を及ぼしている。このような状況を踏まえ, 著者らは, 積雪寒冷地の気象条件と調和した運輸基盤施 設の理論的設計方法の確立に資するため, 凍結融解に起 因する下層路盤の支持力特性の変化とそれに伴う舗装構 造の機能低下を評価可能な長期性能評価手法の提案と, 北方圈の運輸基盤施設に適した寒冷地用路盤構造の要求 性能の提示を目指している. 先行研究 33,4$)$ では, 凍結融解 作用を受ける舗装構造の長期的な挙動予測手法や性能評 価手法の構築には, 下層路盤材のような粒状路盤材の凍 上性を勘案するだけでなく, 凍結融解現象やそれに伴う 粒状路盤材の品質変化, 舖装構造内の土㙵水分量の季節 変動に起因する下層路盤の支持力・剛性変化を考慮する ことが重要であることを明らかにした．このため, 融解 期における下層路盤の力学的応答を数理モデル化し道路 舗装の理論的設計方法に組み込むには，様々な締固め状 態や含水状態における粒状路盤材の力学特性（変形・強 度特性）や浸透特性（保水・透水性）を十分制御された
試験条件の下で精度の高い試験を行い，定量的に明らか にする必要がある。

舗装調查・試験法便覧5)では, 舗装構造の設計計算で利 用される路盤材料を対象とした材料試験方法として, 「E001 修正 CBR 試験方法」と「E016 路盤材・路床土の レジリエントモデュラス試験方法」を規定している．し かし，これらの試験は，一般に，最適含水比における路 盤材料の変形・強度特性の検討を目的としたものであり, 対象土の含水状態がその材料特性に及ぼす影響を詳細に 評価するためのものではない，一方，不飽和土の力学特 性や浸透特性を求める室内要素試験方法は, 試料の材料 特性や試験条件に応じて, これまで多種多様な試験方法 が提案されている. 例えば，地盤材料の保水性試験方法 としては, 遠心法, 土柱法, 吸引法, 加圧法および蒸気 圧法などが提案されているが，各試験方法の適用範囲や 作業性は様々である. このうち, 下層路盤材に対して, 森石ら ${ }^{6}$ は吸引法 (水頭型) で, 石垣ら》は土柱法で保水 性試験を実施している. また, 森石ら ${ }^{6)}$ は, 定常法 (フラ ックス制御型）を用いて下層路盤材の不飽和透水係数を 求めている. ただし, 力学試験については, 海外では, マトリックポテンシャル (サクション) を制御した状態 で不飽和下層路盤材の試験が実施され ${ }^{8), 9,10)}$, 含水比が上 昇するとレジリエントモデュラスが低下することが示さ れているものの, 国内では, 試験実施報告例はほとんど ない. このような状況を踏まえ, 本研究では, 融解期の 
舗装構造内の含水比上昇が下層路盤材の材料性能変化に 及ぼす影響を定量的に評価するため，不飽和土質力学を 応用した路盤材料の新たな力学試験方法を提案する.

\section{2. 研究の概要}

下層路盤材のような砂質土は一般に不飽和状態におい

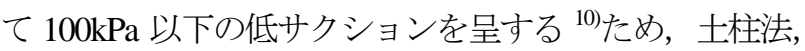
吸引法, 加圧法など低サクション領域の測定が可能な試 験方法が適していると考えられる. 特に, 土柱法や吸引 法に比べ測定範囲が広い加圧法は，下層路盤材のような 不飽和粒状路盤材の力学試験方法として適格である. 加 圧法は，セラミックディスクを使用する加圧板法と，微 細多孔質膜を用いる加圧膜法に分類されるが，一般的に は前者が用いられている. しかし，セラミックディスク は透水性が極めて低いため, 下層路盤材のような大粒径 の試料では供試体寸法が大きくなり, 試験時間が非常に 長くなる. 近年, Nishimura $ら^{11) や I s h i k a w a ~} ~^{12)}$ は，この ような課題を解決寸るために，セラミックディスクの代 わりに微細多孔質膜を用いる加圧膜法で, 不飽和土の各 種要素試験を行い，加圧膜法が試験時間の短縮に有用で あることを報告している.

そこで, 本研究では, 不飽和粒状路盤材の力学挙動評 価に適した実用性の高い要素試験方法の提案を目的とし て, 微細多孔質膜を利用した中型不飽和三軸試験機を開 発し, 下層路盤材の力学試験に対寸るその適用性・有用 性を試験時間の短縮と試験結果の妥当性の観点から検証 する.このため，まず，本研究で開発した中型不飽和三 軸試験機を用いて豊浦砂の保水性試験と三軸圧縮試験を 行い, 既往の研究と比較することで, 開発した試験機の 性能を評価し, 不飽和土を対象とした要素試験への適用 性を検討する．次に，下層路盤材として使用される自然 砕石（Crusher-run，以下「C-40」と称する）の保水性試験 と三軸圧縮試験を実施し，不飽和粒状路盤材の要素試験 に対する試験機および試験方法の適用性・有用性を検討 する. また，併せて，飽和・不飽和粒状路盤材の力学挙 動を含水比と関連付けて把握し, これにより, 舗装構造 内の土壤水分量の季節変動が下層路盤材や下層路盤の力 学特性に及ぼす影響について明らかにする.

\section{3. 中型不飽和三軸試験機}

本研究で使用した試験機は，ハイブリッド・アクチュ エータを用いた変位制御・荷重制御が可能な中型不飽和 三軸試験機である (図-1)。本研究では, 供試体軸変位の 計測は，三軸セル内部キャップ上端に設置した 2 個の線 形電圧差動変圧器 (LVDT) と外部に取り付けた 1 個の

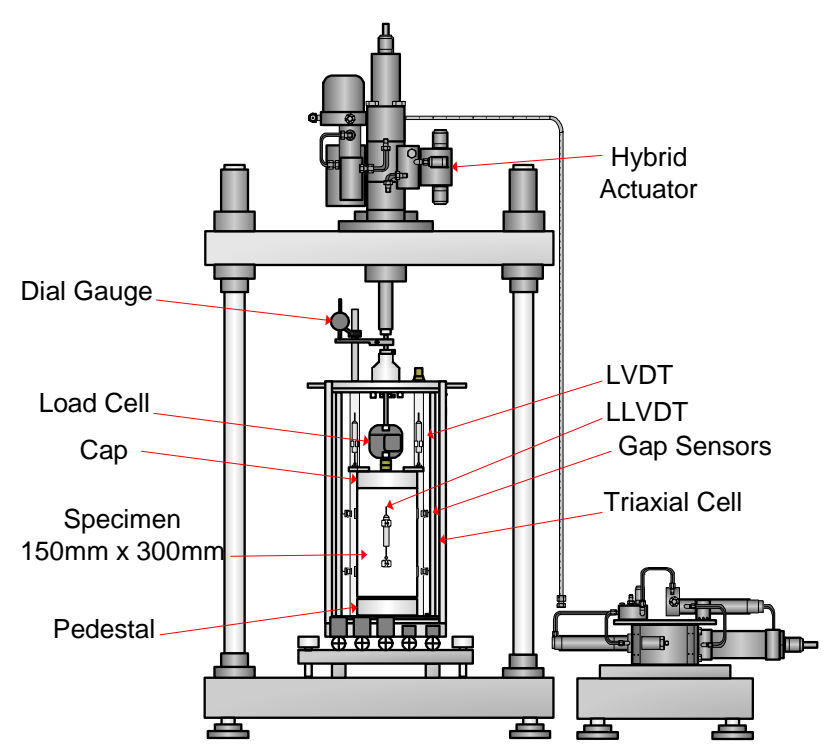

図-1 中型不飽和三軸圧縮試験機

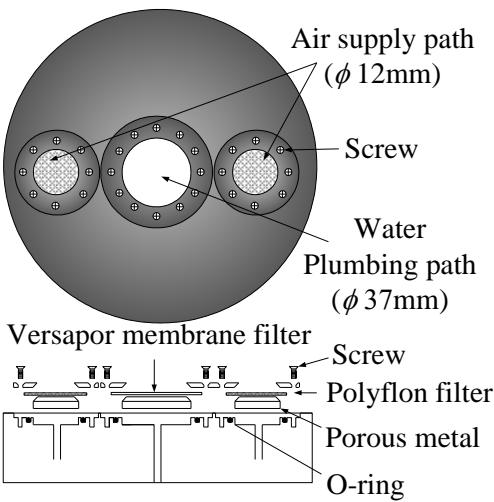

図-2 キャップ・ペデスタルの構造

変位変換器 (外部変位計, EXT) で, 側方変位の計測は, 供試体の対角位置の 2 測線に各々供試体側面上下 2 力所 ずつ, 供試体高さの $1 / 4$ と $3 / 4$ の位置に設置した合計 4 個 の非接触型変位計（ギャップセンサー，GS）でそれぞれ 実施した。

本試験機のキャップ・ペデスタルの構造を図-2 に示す. また, 本試験機の主な特徴は以下のとおりである.

・ 供試体のサイズは, $H=300 \mathrm{~mm}, D=150 \mathrm{~mm}(H / D=2.00)$ である. 下層路盤材に使用されるような粒径の大き な地盤材料を扱うことができるため, 舗装調査・試 験法便覧 ${ }^{5)}$ の E016 路盤材・路床土のレジリエントモ デュラス試験方法に準拠した試験が実施可能である.

- 間隙水圧・間隙空気圧制御経路がペデスタル側およ びキャップ側それぞれに設置されており，供試体両 端からサクション制御および吸排水が可能である. また，フラッシング経路が上部・下部間隙水圧経路 のそれぞれに設置されているため, 給排水経路の飽 和化が容易に行える.

- 軸荷重の載荷は, 従来の油圧駆動装置の課題を解消 するため, 速度可変可逆モータと双方向吐出ポンプ を連動させたハイブリッド•アクチュエータで行う. 
表-1 フィルターの物性值

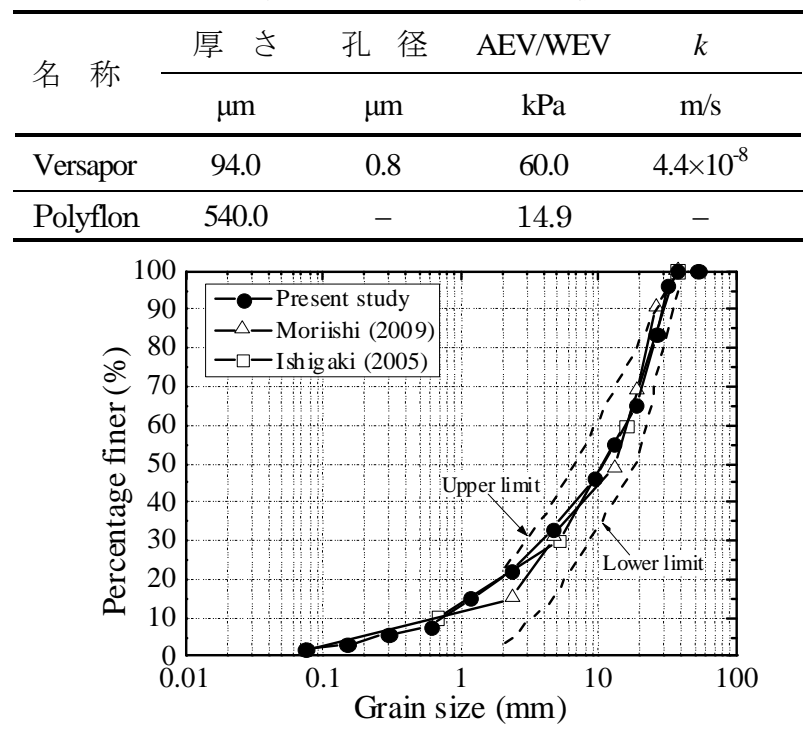

図-3 C-40 の粒径加積曲線

表-2 C-40 の物性値

\begin{tabular}{cccc}
\hline 項 目 & 本研究 & 森石 & 石垣 \\
\hline 土粒子密度 $\rho_{\mathrm{s}}\left(\mathrm{g} / \mathrm{cm}^{3}\right)$ & 2.739 & - & 2.653 \\
\hline 吸水率 $(\%)$ & 3.80 & 0.80 & 0.57 \\
\hline 塑性指数 $\mathrm{PI}$ & $\mathrm{NP}$ & $\mathrm{NP}$ & $\mathrm{NP}$ \\
\hline 最大乾燥密度 $\rho_{\mathrm{dmax}}\left(\mathrm{g} / \mathrm{cm}^{3}\right)$ & 2.070 & 2.062 & 2.105 \\
\hline 最適含水比 $w_{\text {opt }}(\%)$ & 8.2 & 2.0 & 3.0 \\
\hline 修正 $\mathrm{CBR}(\%)$ & 85.8 & 88.2 & - \\
\hline 細粒分含有率 $F_{\mathrm{c}}(\%)$ & 1.7 & 1.2 & - \\
\hline 均等係数 $U_{\mathrm{c}}(\%)$ & 29.2 & 23.9 & 23.6 \\
\hline
\end{tabular}

同載荷装置は，フィードバックコントロール方式を 採用した油圧サーボコントロールシステムを備えて おり，変位制御と荷重制御の両方式による載荷を 1 台のアクチュエーターで高精度に実施可能である. なお，表-1に使用したフィルターの物性值を示す.

\section{4. 試験方法}

\section{（1）供試体作製方法}

試料は既往の研究との比較を行うため，試験報告が豊 富な豊浦砂と下層路盤に使用されている北海道札幌市南 区硬石山で産出される安山岩の $40 \mathrm{~mm}$ 級の切込砕石 C-40 を粒径 37.5mm でカットして使用した. 本試験で使用し た C-40 の粒径加積曲線と物性值を, 図-3, 表-2 に示す. なお，C-40 については，比較する既往研究の試料の值も 合わせて示した。 また，図-3 には，JIS 規格 A5001-1988 で規定されている粒度範囲（上限・下限）も合わせて示 した，供試体の作製は，豊浦砂の場合は，相対密度 $D_{\mathrm{r}}$ が 85\%になるように絶乾試料を落下高さを調整し，MSP 法 13)で作製した.C-40の場合は, 舗装調査・試験法便覧 ${ }^{5)}$ F007 突固め試験方法の結果に基づき締固め度 $D_{\mathrm{c}}=95 \%$ 基本 とした。また，締固めエネルギーを一定にするため，メ

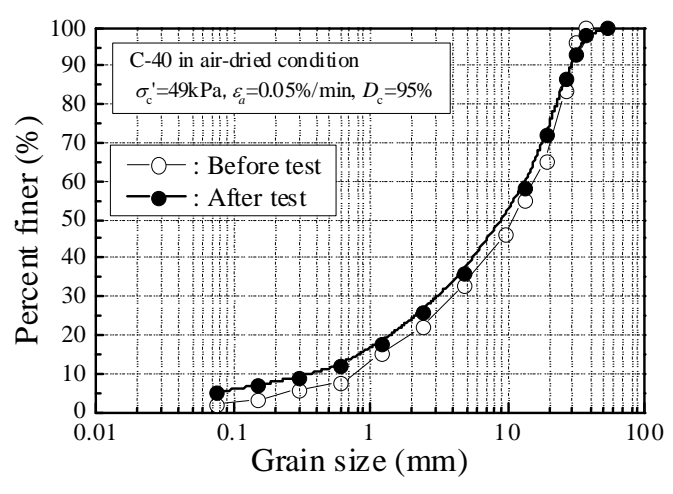

図-4－40 の三軸圧縮試験前後の粒度変化

ンブレンを装着したモールド内に気乾燥試料を 5 層に分 けて投入し，各層毎に上載式振動バイブレーターによっ て一定時間振動締固めて作製した。この時，土粒子の接 触による膜の損傷を防ぐためにキャップ・ペデスタル側 それぞれの全断面にろ紙を敷き, $2 \mathrm{~mm}$ 以下の試料を $5 \mathrm{~mm}$ 程度供試体端面部分に敷き詰めている.ただし,この $2 \mathrm{~mm}$ 以下の試料は，供試体作製時の 5 層のうち供試体最下層 および最上層の細粒分であり，供試体全体としての粒度 分布は変わっていない，このため，当該細粒分層が供試 体の力学挙動に及ぼす影響は小さいと考えられるが，詳 細については今後検討を要する. 本研究では,この状態 を「気乾供試体 $\left(S_{\mathrm{r}}=8.2 \%\right) 」$ と称する.

\section{（2）保水性試験}

気乾供試体作製後, 地盤工学会規準「土の保水性試験 方法」（JGS 0151-2009）に準拠して毛管飽和した豊浦砂と C-40 に対し保水性試験を実施した. ただし, 基底応力 $\sigma_{\mathrm{net}}=49 \mathrm{kPa}\left(\sigma_{\mathrm{net}}=\sigma_{c}-u_{a}\right.$, ここで，拘束圧 $\sigma_{c}=249 \mathrm{kPa}$ ，間隙空 気圧 $u_{a}$ ・間隙水圧 $u_{w}=200 \mathrm{kPa}$ ）で 24 時間程度等方圧密を 行い, その後, 間隙空気圧一定の下, 間隙水圧を減少さ せること（排水過程）で段階的にサクション $s \quad\left(s=u_{a}-u_{w}\right)$ を作用させた. また, 本研究では, 排水量 $0.01 \mathrm{~g} / \mathrm{min}$ 以下 （体積ひずみ $\varepsilon_{v}=1.0 \times 10^{-3} \% / \mathrm{min}$ ）となった時，定常状態に 達したと判断し, 次の段階のサクション $s$ を負荷した. 対象土の水分特性曲線は，この時の供試体の含水比を排 水量から算出して求めている. なお, 本研究では, サク ション負荷に伴う有意な体積変化は確認されなかった.

\section{（3）単調載荷三軸圧縮試験}

気乾供試体作製後，含水状態を調整し，地盤工学会規 準「不飽和土の三軸圧縮試験方法」（JGS 0527-2009）ある いは「土の圧密排水（CD）三軸圧縮試験方法」（JGS 0527-2009）に準拠して，排気・排水条件で豊浦砂と C-40 の等方圧密三軸圧縮試験を実施した．飽和・不飽和・気 乾状態の各供試体の含水状態の設定は以下のように行っ た. 飽和供試体 $\left(S_{\mathrm{r}}=100 \%\right)$ は, $\mathrm{CO}_{2}$ ・脱気水を気乾供試 

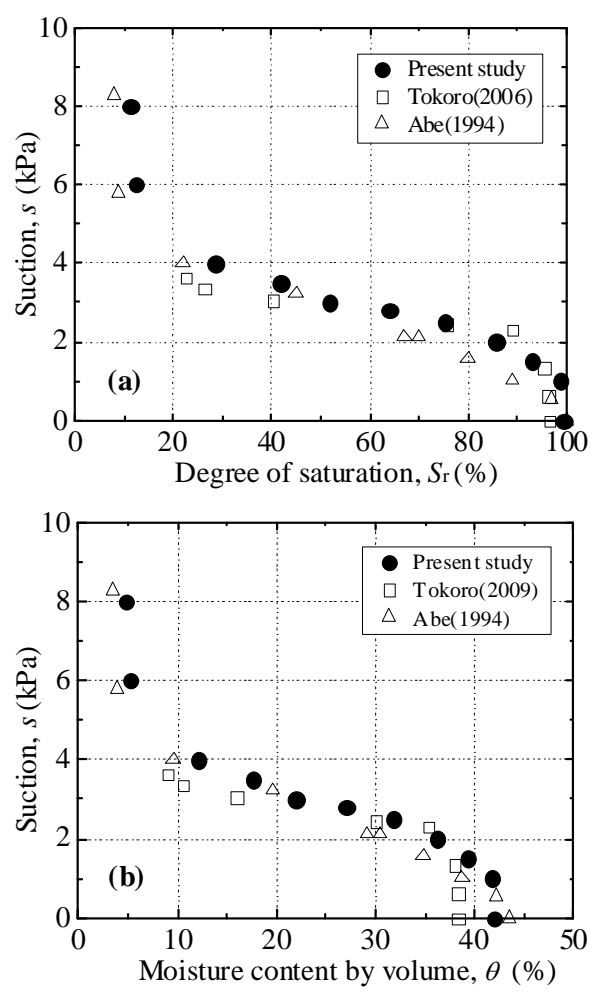

図-5 豊浦砂の水分特性曲線（(a) $: s \sim S_{\mathrm{r}}$ 関係，(b) $: s \sim \theta$ 関係)
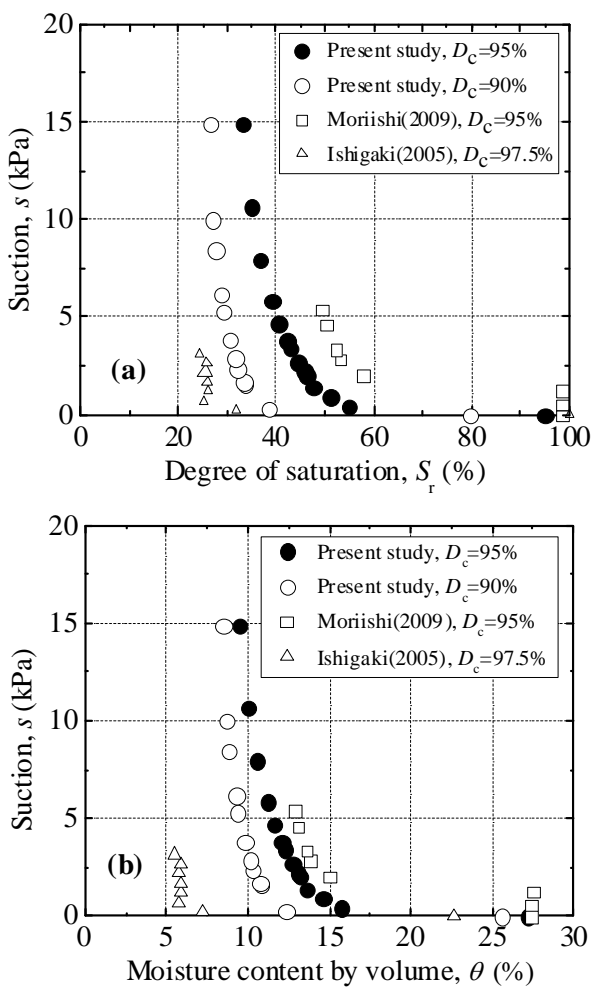

図-6 C-40 の水分特性曲線（(a) : $s \sim S_{\mathrm{r}}$ 関係，(b) : $s \sim \theta$ 関係)

体に所定時間供給した後，背圧負荷（C-40）あるいは二 重負圧法（豊浦砂）により飽和させた。この際，間隙水 圧係数 B 值が 0.96 以上の值であることを確認している. 不飽和供試体 $\left(\mathrm{S}_{\mathrm{r}}=82.3 \%\right.$ あいは $\left.36.7 \%\right)$ は，保水性試験 時と同様の手順で所定のサクション $(s=2.5 \mathrm{kPa}$ あるいは 10kPa）を負荷して作製した. なお，C-40の場合，不飽和 供試体の飽和度は，後述のように，実舗装構造の下層路 盤の通常時の飽和度を考慮して設定した．供試体の含水 状態設定後，軸変位と排水量が一定になるまで，所定の 有効拘束圧 $\left(\sigma_{c}=49 \mathrm{kPa}\right.$ あるいは $\left.\sigma_{\mathrm{net}}=49 \mathrm{kPa}\right)$ で供試体を 等方圧密した．続いて，有効拘束圧一定の下で所定の軸 ひずみ速度の単調載荷三軸圧縮試験 (CD 試験) を行った. なお，軸ひずみ速度は，C-40については，地盤工学会規 準に準拠して 0.05\%/min としたが，豊浦砂については, 過去の試験結果との比較のため $0.5 \% / \mathrm{min}$ に設定した. ま た，不飽和および気乾供試体の体積ひずみは，Kato ら ${ }^{14)}$ が提案した計算方法を参考に，ギャップセンサーの測定 結果をもとに算出した．なお，供試体作製前と三軸圧縮 試験終了後にふるい分析による粒度試験を行い，試験前 後の供試体の粒度変化を調べた（図-4)。供試体作製ある いは圧密・せん断に伴う粒子破砕等による粒度変化が確 認された. また, 砕石粒子の接触に伴う微細多孔質膜の 機能障害の有無を検討するため, 不飽和条件の試験では, 試験後にバーサポアメンブレンの AEV 検定を実施し, 試 験中に微細多孔質膜の損傷がないことを確認している.

\section{5. 試験結果と考察}

\section{（1）保水性試験結果}

\section{a）豊浦砂の水分特性曲線}

豊浦砂の水分特性曲線（SWCC）を図-5（但し， $\theta$ : 体 積含水率) に示寸. 同図には, 阿部 $\left.{ }^{15}\right)$ が加圧板法 $(H=20 \mathrm{~mm}$, $D=50 \mathrm{~mm}, e=0.77$ ) で求めた SWCC と, 所ら ${ }^{16)}$ が加圧膜 法 $(H=30 \mathrm{~mm}, D=70 \mathrm{~mm}, e=0.66)$ で求めた SWCC を併 せて示した. 本研究で得られた SWCC は, 飽和度の低下 に伴いサクションが増加する変曲点をもつ $\mathrm{S}$ 字型曲線を 呈しており，その形状は既往研究と定性的に一致する. また, 本研究の SWCC では, 空気侵入值 (AEV) が 1.48kPa, 残留飽和度 $S_{10}$ は $10.98 \%$ (残留体積含水率 $\theta_{0}=4.61 \%$ ) と なった.この $\mathrm{AEV}$ は, 所らの試験結果（AEV=2.30kPa） に比べ若干低いものの，阿部の試験結果とは概ね一致し ている. 他方, $S_{10}$ に関しても, 本研究・阿部の試験結果 ともに, 10\%程度の值を示しており, 概ね一致している.

これらは，豊浦砂の保水性試験に対寸る本試験機の適用 性の高さを示寸結果である. なお，本研究のように供試 体サイズの大きな不飽和条件の要素試験では, 供試体の 含水比分布の一様性の保証が一つの課題となる. このた め, 保水性試験終了後に供試体高さ方向の飽和度分布を 厚さ $5 \mathrm{~cm}$ 毎に調べた. その結果, 供試体中央部の飽和度 が若干高くなる傾向は見られるものの, サクションが制 御されている供試体上下端面より $10 \mathrm{~cm}$ 程度の範囲では, 飽和度がほぼ一定となり, 試験時の供試体の含水状態は ほぼ一様とみなせることを確認している. 
一方，試験時間の短縮効果については，加圧膜法の試 験では, 加圧板法の試験に比ベサクション負荷に伴う排 水時間が 100 倍程短縮されたことが報告されている ${ }^{12)}$. そこで，同じ加圧膜法を採用している所らの試験結果と 本研究の試験時間を比較した. その結果, 供試体断面に 対する給排水経路の面積比率には明確な相違は見られな いものの, $s=0$ から $2.0 \mathrm{kPa}$ までのサクション負荷に要し た平衡時間は, 本研究では 1368 分, 所らの研究では 84 分であり, 本研究の方が 16.3 倍長くなった. ただし, 本 研究の供試体寸法は所の研究の 10 倍であり, 一般に平衡 時間は供試体高さの二乗に比例することを考慮すると，

本研究の排水速度は供試体寸法が大きい割には早い。こ の理由として, 所らの研究では, 供試体上面からの片面 排水で保水性試験を実施しているが，本研究では両面排 水のため最大排水長が供試体高さの半分であることが挙 げられる，実際，同一試験条件で，片面排水で保水性試 験を実施した場合， $s=0$ から $2.0 \mathrm{kPa}$ までのサクション負 荷に要した平衡時間は5206分と両面排水よりも3.81倍長 くなった. 以上のことから, 本研究のように供試体寸法 の大きな保水性試験では，加圧膜法を用いた両面排水が 試験時間の短縮に有効であると考えられる.

\section{b) C-40 の水分特性曲線}

締固め度 $D_{\mathrm{c}}=95 \%$ と $90 \%$ の C-40 の SWCC を図-6 に示 す. 同図には, 森石ら ${ }^{6}$ の吸引法 $(H=125 \mathrm{~mm}, D=150 \mathrm{~mm}$, $\left.D_{\mathrm{c}}=95 \%\right)$ で求めた SWCC と, 石垣ら゙が土柱法 $(H=480 \mathrm{~mm}$, $\left.D=305 \mathrm{~mm}, D_{\mathrm{c}}=97.5 \%\right)$ で求めた SWCC を併せて示した. C-40 の SWCC は, 豊浦砂の SWCC とは異なり, サクシ ヨン負荷と同時に急激な排水が生じており, AEV が明確 に認められない J 字型曲線となった. また, C-40 ( $\left.D_{\mathrm{c}}=95 \%\right)$ の $S_{10}$ は $31.9 \%$ （残留体積含水率 $\theta_{0}=9.13 \% ）$ となり, 豊浦 砂に比べて水分保持能力が高いことがわかる. これは, 豊浦砂に比べ C-40 は粒度分布が良く $\left(U_{\mathrm{c}}=29.2\right)$, 細粒分 を多く含有していること $\left(F_{\mathrm{c}}=1.7 \%\right)$ によると考えられる

(表-2). なお，表-2 に示すように, 本研究で用いた C-40 は吸水率が高いことから, 砕石粒子自体の吸水・排水に よる保水性試験中の飽和度の測定誤差が危惧される。 そ こで, 保水性試験中の吸水率の影響を確認するため,「粗 骨材の密度及び吸水率試験方法」(JIS A 1110) に準拠して, (1)保水性試験終了後, (2)炉乾燥後に新たに 24 時間吸水さ せた場合，(3)保水性試験で通水から圧密終了に要した時 間を吸水させた場合の 3 種類の試験条件で, 砕石粒子の 吸水率を計測した. その結果, 吸水率は, (1)3.07\%, (2)3.06\%, (3)3.10\%となり，顕著な差は見られなかった. このことか ら, 圧密終了後は土粒子一または土粒子からの間隙水の 吸排水はなく，本試験方法で計算される飽和度は，土粒 子の吸水率に依存しないと結論できる.

次に, 本研究で得られた C-40 の SWCC を既往の試験 結果と比較する，なお，図-3，表-2 に示すように試験に

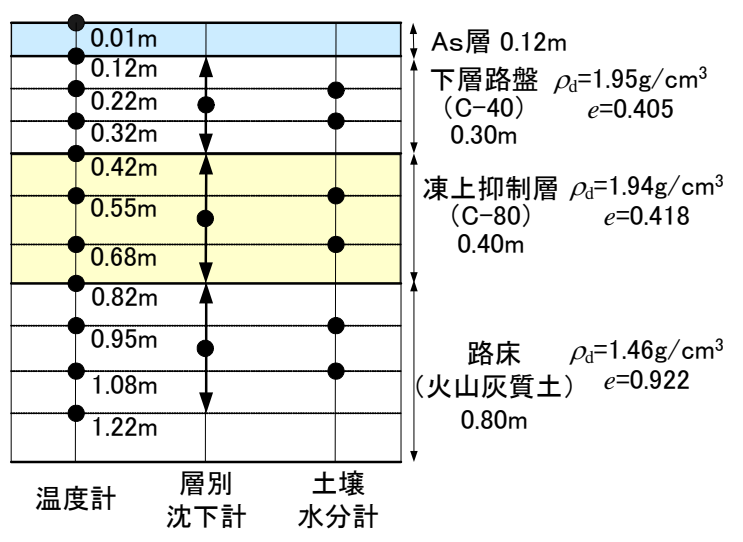

図-7 試験舗装構造の概略（苫小牧）

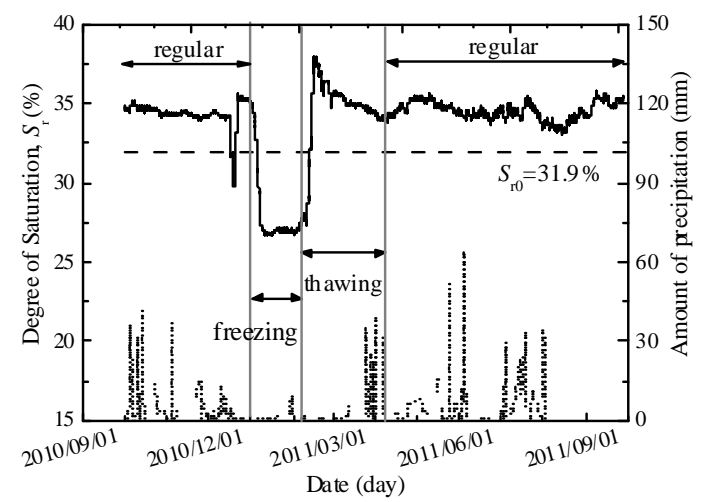

図-8 下層路盤の飽和度の長期計測結果（苫小牧）

使用したC-40 は, 各試料とも比較的類似した物理的性状 を呈している. 本研究の SWCC は, AEV が視認できる森 石らの試験結果とは異なるものの, 類似の形状は石垣ら の試験結果や海外の試験結果でも得られており，C-40の 空気侵入值は非常に小さい值であると考えられる. 一方, 本試験結果では, 同じ試料であっても $D_{\mathrm{c}}$ が減少すると $S_{10}$ も低下寸る傾向にあるが, 本研究と石垣らのSWCC の比 較では, 石垣らのD 本研究の $S_{10}$ は石垣らの試験結果より 10\%程度高い. これ は, 石垣らの試料に比べ, 本研究の試料の方が全体的に 細粒な粒子が多く（図-3）供試体内の間隙サイズが小さ くなったため, 水分をより多く保持したと考えられる. 以上のことから, 本試験結果は, 既往の研究と粒度分布 や締固め度により定量的には水分保持特性が異なるもの の，定性的には概水一致しており，下層路盤材の保水性 試験方法として適用可能であると考えられる.

前述のような室内要素試験結果を, (独) 土木研究所 寒 地土木研究所苫小牧試験道路に造成した試験舗装 (図-7) 3)で長期計測された下層路盤 $\left(D_{\mathrm{c}}=94.2 \%\right)$ の含水状態と比 較する. なお, 当該試験舗装区域における地下水位は, 地質調査結果より路床底面より約 $2.5 \mathrm{~m}$ 下であることが判 明している. 図-8 は, 試験舗装で計測された下層路盤の 飽和度および日降水量の経時変化である. 当該試験舗装 の下層路盤は, 本研究の試験条件よりも締固め度が若干 低いものの, 本研究で用いたC-40で構成されている. 図 


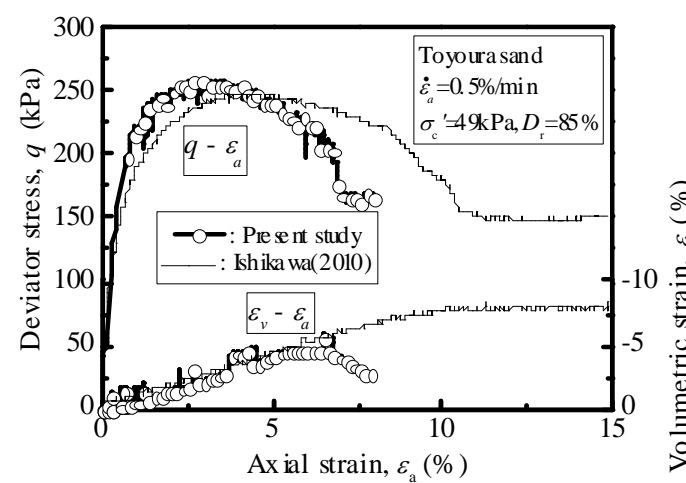

図-9 豊浦砂の単調載荷三軸圧縮試験結果

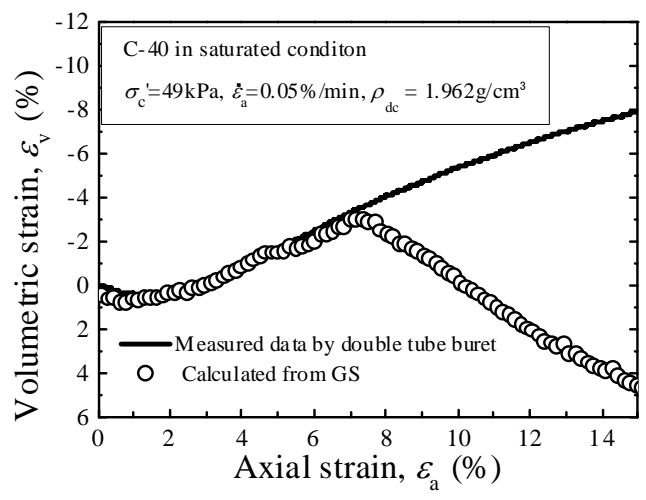

図-10 体積ひずみ計算方法の検証（飽和 C-40）

から，凍結期や融解期を除く通常期の飽和度は，降雨に よる変動に関わらず 35\%程度でほぼ一定であり，融解期 には，凍結前より飽和度が一時的に増加し最高 38\%程度 まで上昇することがわかる．図-6 と比較すると，通常期 における実下層路盤の飽和度は，残留飽和度と定量的に ほぼ一致しており，最適含水比に対応した飽和度 55.4\% に比べかなり低い。このため，実際の舗装構造では，通 常期の下層路盤は残留飽和に近い状態にあると考えられ る. また，通常期から融解期に観測される含水状態の変 化は，飽和度変化に対するサクションの変動が大きい懸 垂水不飽和状態加過渡的不飽和状態への遷移領域に相 当することから，下層路盤材の力学挙動に対する含水状 態の影響もより顕著に表れると推定される.

\section{（2）単調載荷三軸圧縮試験結果}

\section{a）豊浦砂の応力〜ひずみ関係}

図-9 は，不飽和条件 $\left(s=2.5 \mathrm{kPa}, S_{\mathrm{r}}=82.3 \%\right)$ で害施した 豊浦砂の単調載荷三軸圧縮試験より得た, 軸差応力 $q$

$\left(=\sigma_{a}-\sigma_{c}\right.$ ，ただし， $\sigma_{a}$ : 軸圧 $)$ 〜軸ひずみ $\varepsilon_{a}$ 関係と体積ひ ずみ $\varepsilon_{v}\left(=\varepsilon_{a}+2 \varepsilon_{r}, \varepsilon_{r}\right.$ : 側方ひずみ $)$ 軸ひずみ $\varepsilon_{a}$ 関係（ダ イレイタンシー特性）である。同図には，供試体寸法以 外の試験条件がほぼ同一の既往研究 $(H=170 \mathrm{~mm}$, $D=70 \mathrm{~mm}){ }^{12)}$ で求めた $q \sim \varepsilon_{a}$ 関係と $\varepsilon_{v} \sim \varepsilon_{a}$ 関係を併せて示 した。 なお，豊浦砂の試験では，既往研究における軸変 位の測定位置と合わせるため, 図-1 に示寸外部変位計に

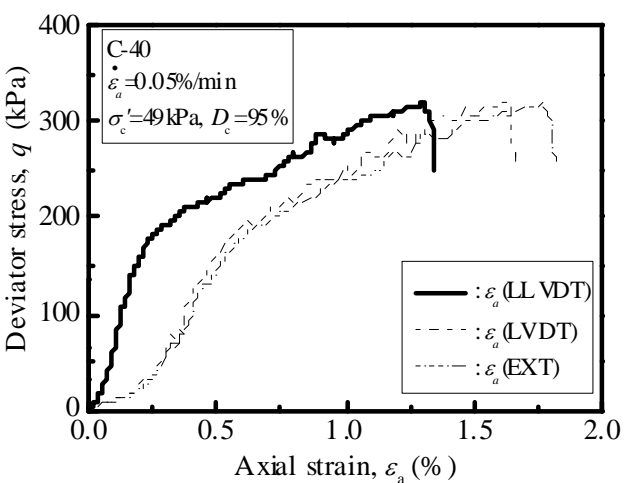

図-11 計測方法による応力〜ひずみ関係への影響

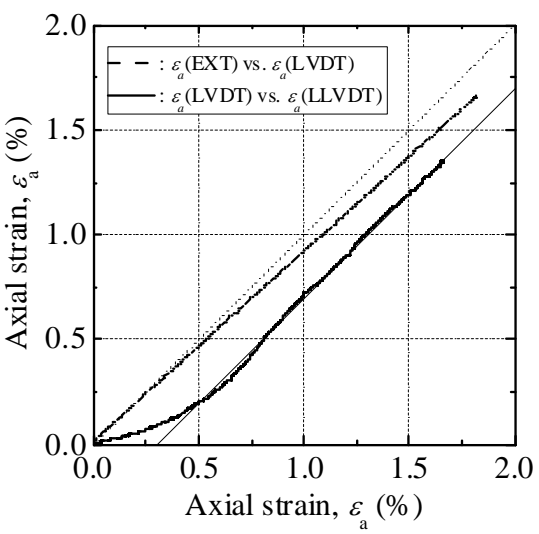

図-12ＳC と BE に起因する計測誤差の影響

より計測した軸ひずみを用いた．本試験結果の場合，試 験中のアクシデントにより軸圧載荷が目標より小さい值 で停止してしまったため残留状態には達していないが, 5\%以下の軸ひずみで最大軸差灾力を示し，その後軸ひず みの増加とともに軸差応力が低下するひずみ軟化型の応 力〜ひずみ関係を示した. また，最大軸差応力および最 大軸差応力までのダイレイタンシー特性は含水状態に関 わらず既往の試験結果と定量的に概ね一致した．以上の ことから，地盤材料の三軸圧縮試験に対寸る本試験機の 適用性は高いと考えられる.

b）計測方法の妥当性の検討

飽和C-40 の単調載荷三軸圧縮試験から得られた軸ひず み $(\mathrm{EXT}) \varepsilon_{a}$ 〜体積ひずみ $\varepsilon_{v}(\mathrm{GS})$ の関係を図-10 に示す. 同図には，二重管ビューレットで計測される排水量から 算出した体積ひずみの結果も併せて示した. ギャップセ ンサー（GS）を用いて体積ひずみは，二重管ビュレット を用いたものと概及一致している。しかし，ピーク強度 を超えた軸ひずみが 7\%以降では,両者の計測結果に違い が認められる. これは, 供試体全体の変形量を GS 設置位 置の側方変位から推測する計算方法では，ピーク強度を 超え土のせん断抵抗が急激に減少し，せん断帯に代表さ れるように変形およびひずみの局所化が顕在化するひず み軟化型の変形挙動を充分に表現するのが難しいためで ある.同様な現象は同じひず夕軟化型挙動を示す豊浦砂 の三軸圧縮試験（図-9）でも確認できる.したがって, 


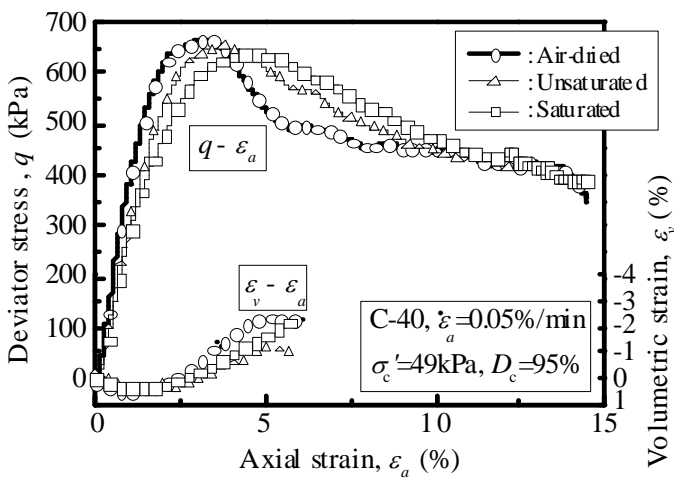

図-13 C-40 の単調載荷三軸圧縮試験結果

本研究で採用した体積ひずみの計算方法の信頼性は，ピ ーク強度を超えた軸ひずみ範囲では低いと考えられる.

一方，地盤材料の室内要素試験では，外部変位計で軸 変位量を精確に測定する場合の計測上の課題として，シ ステムコンプライアンス (SC) やベディングエラー (BE) の影響が報告されている．特に，碩などの硬質地盤材料 を対象にした場合に, BE は大きくなるとされている ${ }^{17)}$. そこで，これらの計測誤差の影響を検討するため，前述 の外部変位計（EXT）と LVDT に加え, AASHTO T274-82(1986)に準拠し供試体側面中央の対角位置の 2 側 線と平行にLVDT（以下，区別のため「LLVDT」と称す） を設置して，軸ひずみ 2\%までの毛管飽和 C-40 の単調載 荷三軸圧縮試験を別途実施した。同試験から得られた軸 差応力 $q$ 軸ひずみ $\varepsilon_{a}$ 関係を図-11 に示す. 同一応力レベ ルで異なる計測方法による軸ひずみを比較すると，軸差 応力の值に関わらず $\varepsilon_{a}$ (LLVDT), $\varepsilon_{a}$ (LVDT), $\varepsilon_{a}$ (EXT) の順で大きくなった. この際, $\varepsilon_{a}$ (LVDT) と $\varepsilon_{a}(\mathrm{EXT})$ の差は主に SC の影響を表すと考えられるが, 図-12 に示 すように，SCに起因する計測誤差は $\varepsilon_{a}$ (EXT) の 1 割程 度でありその影響はひずみレベルに依らずほぼ一定であ る. 他方， $\varepsilon_{a}$ (LLVDT) と $\varepsilon_{a}$ (LVDT) の差異は主に BE の影響を表すと考えられるが， $\varepsilon_{a}$ (LVDT) $=0.5 \%$ 程度を 境にして両者の比が変化していることから, BE の影響は 載荷初期に強く表れる傾向にある. 以上のことから, C-40 の変形挙動を検討する場合，SC と BE の影響を評価する 必要がある. 本研究では，このような計測誤差を除去す るため，外部変位計で測定した軸ひずみを補正して用い た. なお，図-11では，LLVDT による局所変形計測結果 においても $q \sim \varepsilon_{a}$ 関係がS字型を示している.この原因が, 本来の物性を反映したものかあるいは本研究の計測方法 に起因したものかについては, 今後, 検討の余地がある.

\section{c） C-40 の応力〜ひずみ関係}

図-13 は, 各種含水状態で実施した C-40 の単調載荷三 軸圧縮試験より得た, $q \sim \varepsilon_{a}$ 関係とダイレイタンシー特性 である．各含水状態とも，5\%以下の軸ひずみで最大軸差 応力を示し，その後軸ひずみの増加とともに軸差応力が
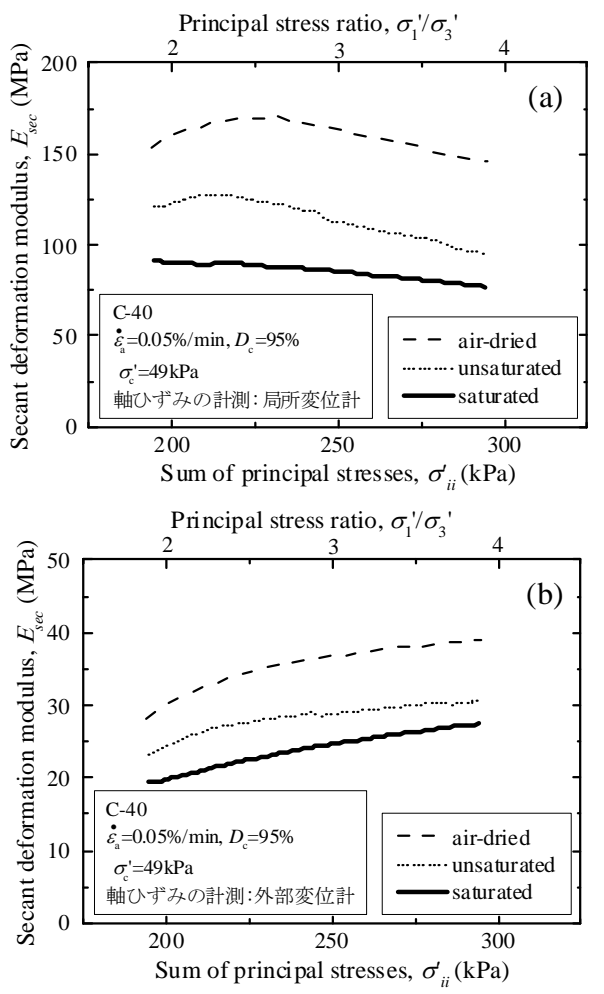

図-14 主态力比 - 主応力和〜割線変形係数関係

表-3 飽和条件の割線变形係数に対する割線变形係数比

\begin{tabular}{|c|c|c|c|c|c|c|c|}
\hline \multirow[b]{2}{*}{ 主応力比 } & \multirow[b]{2}{*}{ 試験条件 } & \multirow[b]{2}{*}{$\begin{array}{c}\text { 主応力和 } \\
\text { (kPa) }\end{array}$} & \multicolumn{2}{|c|}{ 局所計測 } & \multicolumn{2}{|c|}{ 外部計測 } & \multirow{2}{*}{$\begin{array}{l}\text { 剛性比 } \\
\text { (外部／ } \\
\text { 局所） }\end{array}$} \\
\hline & & & $\begin{array}{c}E_{\mathrm{sec}} \\
(\mathrm{MPa})\end{array}$ & $R_{\mathrm{E}}$ & $\begin{array}{c}E_{\mathrm{sec}} \\
(\mathrm{MPa})\end{array}$ & $R_{\mathrm{E}}$ & \\
\hline \multirow{3}{*}{2} & 気乾 & 195.9 & 156.3 & 1.70 & 29.0 & 1.49 & 0.185 \\
\hline & 不飽和 & 195.5 & 121.4 & 1.32 & 23.5 & 1.21 & 0.194 \\
\hline & 飽和 & 195.5 & 91.7 & 1.00 & 19.5 & 1.00 & 0.212 \\
\hline \multirow{3}{*}{3} & 気乾 & 243.9 & 165.4 & 1.91 & 36.3 & 1.50 & 0.220 \\
\hline & 不飽和 & 244.8 & 115.9 & 1.34 & 28.7 & 1.19 & 0.248 \\
\hline & 飽和 & 243.7 & 86.7 & 1.00 & 24.2 & 1.00 & 0.279 \\
\hline \multirow{3}{*}{4} & 気乾 & 293.3 & 146.3 & 1.89 & 39.0 & 1.43 & 0.267 \\
\hline & 不飽和 & 292.7 & 95.8 & 1.24 & 30.5 & 1.12 & 0.318 \\
\hline & 飽和 & 292.9 & 77.4 & 1.00 & 27.3 & 1.00 & 0.353 \\
\hline
\end{tabular}

低下するひずみ軟化型の応力〜ひずみ関係を示した．こ の際, 最大軸差応力は, 飽和, 不飽和, 気乾の順に大き くなり, 主応力比 13 程度までの範囲について比較した場 合，同一軸差応力の軸ひずみは，逆に気乾，不飽和，飽 和の順で大きくなった．これは，含水状態による土粒子 間の摩擦抵抗の変化およびサクションの低下に伴う見掛 けの粘着力の減少による影響であると考えられる. また, 含水状態に関わらず，載荷初期に体積が収縮した後，軸 ひずみの増加に伴って体積部脹が生じるダレイタンシー 特性を示している. この際, 正のダイレイタンシ一挙動 は，気乾，飽和，不飽和の順で強まる傾向にある。これ は，供試体内に生じるサクションが土粒子骨格を保持し ようとしたため, 気乾・飽和条件と比較して体積ひずみ 量が小さくなったためと考えられる. 以上のことから， 下層路盤における土壤水分量の季節変動は，下層路盤材 の変形・強度特性に影響を及ぼすと結論できる．なお， 同一C-40 に対する CBR 試験 ${ }^{19)}$ でも含水比の増加に伴う CBR の低下が報告されており，上記の試験結果はこれと 軌を一にするものである. 
各種含水状態で実施したC-40の単調載荷三軸圧縮試験 より得た, 主応力比 $\sigma_{1}{ }_{1} / \sigma_{3} \cdot$ 主応力和 $\sigma^{\prime}{ }_{i i} \sim$ 割線変形係数 $^{\prime}$ $E_{\mathrm{sec}}$ 関係を，路盤材のレジリエントモデュラス（MR）試 験の荷重条件の範囲（主応力比=2〜4）について, 図-14 に示寸. ここで, 割線変形係数 $E_{\mathrm{sec}}$ は, $\left(\sigma_{1}^{\prime}-\sigma_{3}^{\prime}\right) / \varepsilon_{a}$ で定義 する. 同図(a)には $\varepsilon_{a}$ (LLVDT) による局所計測に基づき 算出された $E_{\mathrm{sec}}$ を，同図(b)には $\varepsilon_{a}(\mathrm{EXT})$ による外部計 測に基づき算出された $E_{\mathrm{sec}}$ をそれぞれ示した. なお，主㐫 力和 $\sigma_{i i}{ }^{\prime}$ は, $\sigma^{\prime}{ }_{i i}=\sigma_{1}+2 \sigma_{3}{ }_{3}$ で定義され, MR 試験で求められ るレジリエントモジュラス $M_{\mathrm{r}}$ と関係付けられる指標 ${ }^{18)}$ である. 同図から, 外部計測による $E_{\mathrm{sec}}$ は, 含水状態に関 わらず, 同じ主応力比（主応力和）の局所計測による $E_{\mathrm{sec}}$ の2〜3 割程度であり, 全体的にかなり小さいことがわか る. また, 外部計測による $E_{\mathrm{sec}}$ は, 含水状態に関わらず主 応力比の増加に伴い低下寸るが, 局所計測による $E_{\mathrm{sec}}$ は逆 に増加する傾向にある. これらは, 前述した SC や BE に 起因する計測誤差の影響であると推定されるため, 路盤 材の弾性係数を MR 試験に依らず単調載荷三軸圧縮試験 から求める場合には，計測方法および試験結果の評価に 充分な注意を払う必要がある.

一方，表-3 は，含水状態が $E_{\text {sec }}$ に及ぼす影響を定量的 に検討するため, 飽和条件の $E_{\mathrm{sec}}$ に対寸る各含水状態の $E_{\mathrm{sec}}$ の比を「割線変形係数比 $R_{\mathrm{E}} 」$ と定義し, 局所計測と外 部計測に分けて示したものである. 同表では，通常期を 示寸残留飽和度から融解期のような高含水状態に変化す ると, 主応力比によっては $E_{\mathrm{sec}}$ が 3 割近くも低下寸る場合 のあることが局所計測結果から読み取れる。このような 傾向は, 既往の C-40の MR 試験結果 ${ }^{20)}$ と定性的に一致す る. 以上のことから, 不飽和粒状路盤材の力学特性評価 に対する本研究で開発した中型不飽和三軸厂縮試験機の 適用性は高いと結論できる. なお，外部変位計による外 部計測結果では, 局所計測に比べ含水比上昇に伴う $E_{\mathrm{sec}}$ の低下割合が少ない，このため，計測誤差を多く含む試 験結果によると，下層路盤の变形挙動に対寸る含水状態 の影響を過小評価する恐れがあると考えられる.

\section{6. まとめ}

本研究で得られた主な知見は次の通りである.

(a) 本研究では, 不飽和粒状路盤材の力学挙動評価に適 した実用性の高い室内要素試験方法として，セラミ ックディスクの代わりに微細多孔質膜を採用するこ とで試験時間の短縮を図った，変位・荷重制御がと もに可能な中型不飽和三軸試験機を新規開発した.

(b) 豊浦砂の水分特性曲線は, 空気侵入值 - 残留飽和度 曲線形状の点で既往の試験結果と概ね一致した。 ま た, 供試体寸法の大きな保水性試験では, 加圧膜法
の採用と供試体両端面からの吸排水経路の確保が試 験時間の短縮に有効である.

(c) C-40 の水分特性曲線では, 明確な空気侵入值は認め られず，豊浦砂に比べ残留飽和度は高くなった。一 方, 本研究の水分特性曲線は, 既往の研究と定性的 な傾向はほぼ一致したが，粒度や細粒分含有量の違 いにより空気侵入值や残留飽和度には差が見られた。

(d) 本研究で採用した体積ひずみの計算方法は, ピーク 強度に達するまでの軸ひずみの範囲において有効で ある.また，C-40 の変形挙動を検討する場合，試験 機自体が内包寸る計測誤差や供試体作製方法に起因 する計測誤差の影響を評価する必要がある.

(e) 本試験結果が既往の研究と定性的に一致寸ることか ら, 粒状路盤材の不飽和三軸圧縮試験に対寸る本研 究で開発した試験機の適用性は高い.また，含水状 態の変化は下層路盤材のような粒状路盤材の変形・ 強度特性に強い影響を及ぼすことが明らかになった。 以上の結果から, 不飽和粒状路盤材の要素試験に対す る本研究で開発した試験機および提案する試験方法の適 用性・有用性が示された. また，積雪寒冷地の融解期に 観測される下層路盤の含水比上昇が，下層路盤材の強度 や岡性を低下させ，下層路盤の支持力性能を変化させる ことも明らかになった. しかしながら, 本研究の知見は, 限られた試験条件のもとで得られたものであり，実務へ の本研究成果の応用に際しては, 今後, 試験の再現性や 妥当性あるいは試験結果の評価や適用性等に関する十分 な検討が必要である.

謝辞 : 本研究の実施にあたっては，北海道電力（株）瀬 川宙郷氏に多大なご協力を頂きました.ここに記して深 甚なる謝意を表します. なお, 本研究の一部は平成 23 年 度 平成 26 年度科学研究費補助金（基盤研究(B), 課題 番号: 23360201, 研究代表者: 石川達也) の交付を受け て実施されたものである.

\section{参考文献}

1) 久保宏: 積雪寒冷地舖装の凍上対策, 土木学会誌, Vol.64, No.2, pp.10-16, 1979.

2) 土木学会舗装工学委員会編 : 舗装工学ライブラリー6 積 雪寒冷地の埔装, 土木学会, pp.147-155, 2011.

3）石川達也, 安倍隆二, 吉田有喜, 三浦清一: 粒状路盤の力 学挙動に及ぼす凍結融解作用の影響評価, 土木学会舗装工 学論文集, 第 15 巻, pp.201-209, 2010.

4) 石川達也, 川端伸一郎, 龟山修一, 安倍隆二, 小野丘 : 埔 装構造の疲労寿命に及ぼす粒状路盤の凍結融解の影響とそ の評価，土木学会論文集 E1 (舗装工学)，Vol.67，No.3 (舗 装工学論文集第16 巻), I_109-I_116, 2011.

5）（社）日本道路協会: 舗装調查·試験法便覽 [第 4 分冊], 2007. 
6) 森石一志, 大西有三，西山哲，矢野隆夫，小関裕二 : 粒状 路盤材が透水性舗装および而久付に及ぼす影響, 土木学会 舗装工学論文第 14 巻, pp.25-32, 2009.

7) 石垣勉, 根本信行 : 粒状路盤材の透水特性と水分保持特性 に関する検討, 土木学会第 60 回年次学術講演会論文集, pp.233-234, 2005.

8) Coronado, O., Fleureau, J., Correia, A., Caicedo, B. : Influence of suction on the properties of two granular road materials., In I. Horvli (ed), The 7th International Conference on the Bearing Capacity of Roads, Railways and Air-fields; Proc. intern. conf., Trondheim, 27-29 June 2005., [1/1(CD-ROM)260], 2005.

9) Craciun, O., Lo, S.-C. R. : Matric suction measurement in stress path cyclic triaxial testing of unbound granular base materials, Geotechnical Testing Journal, 33(1), pp.33-44, 2012.

10) Ekblad, J., Isacsson, U. : Water in coarse granular materials: Resilient and retentive properties, In Ellis, Yu, McDowell, Dawson \& Thom (eds), Advances in Transportation Geotechnics, Proc. intern. conf., Nottigham, 25-27 August 2008, pp.117-123, 2008.

11) Nishimura, T., Koseki, J. Fredlund, D.G., Rahardjo, H. : Microporous membrane technology for measurement of soil-water characteristic curve, Geotechnical Testing Journal, 35(1), pp.1-8, 2012.

12) Ishikawa, T., Tokoro, T., Ito, K., Miura, S. : Testing methods for hydro-mechanical characteristics of unsaturated soils subjected to one-dimensional freeze-thaw action, Soils and Foundations, 50(3), pp.431-440, 2010.

13) Miura, S., Toki, S. : A sample preparation method and its effect on static and cyclic deformation-strength proper-ties of sand, Soils and Foundations, 22(1), pp.61-77, 1982.

14) Kato, S., Kawai, K. : Deformation characteristics of a compacted clay in collapse under isotropic and triaxial stress state, Soils and Foundations, 40(5), pp.75-90, 2000.

15）阿部廣史 : 不飽和土の力学特性の評価法に関する実験的研 究, 東京大学学位論文, p.197, 1994.

16）所哲也，石川達也，三浦清一 : 給排水経路の断面積が砂の 不飽和透水係数に及ぼす影響, 第 44 回地盤工学研究発表会 発表講演集, pp.963-964, 2009.

17）龍岡文夫, 木幡行宏:ベディングエラー, 土と基礎, Vol.42, No.9, pp.53-55, 1994.

18) 阿部長門, 杂隹賀義夫:路盤材料のレジリエントモデュラス, 舗装, Vol.29-6, pp.9-13, 1994.

19) 村山巧，川端伸一郎，小野丘，石川達也：凍結融解作用が 粒状路盤材の CBR に与える影響について，土木学会第 66 回年次学術講演会論文集, pp.807-808, 2011.

20) 安倍隆二, 熊谷政行, 丸山記美雄 : 積雪寒冷地におけるア スファルト舗装の理論的設計方法に用いる材料特性および 環境条件に関する検討, 土木学会舗装工学論文集, 第16巻, pp.17-25, 2011.

\section{APPLICATION OF TRIAXIAL APPARATUS FOR UNSATURATED SOILS TO MECHANICAL BEHAVIOR OF GRANULAR BASE COURSE MATERIAL}

\section{Tatsuya ISHIKAWA, Yuan ZHANG and Tetsuya TOKORO}

This paper proposes a testing method for evaluating the effect of water content on the deformation-strength characteristics of unsaturated base course materials. A medium-size triaxial apparatus for unsaturated soils was newly developed in order to examine the mechanical behavior of unsaturated base course materials subjected to fluctuation in water content and to shorten the testing time. Results show that the proposed testing method carried out on this apparatus conform well to the results of previous researches. This indicates that the medium-size triaxial apparatus is highly useful at triaxial compression tests and water retention tests of unsaturated granular base course materials and in shorten the total testing time. 